\title{
TOXICOLOGICAL PROPERTIES OF CITRININ
}

\author{
Dubravka FLAJS and Maja PERAICA \\ Institute for Medical Research and Occupational Health, Zagreb, Croatia
}

Received in August 2009

Accepted in August 2009

\begin{abstract}
Citrinin (CTN) is a nephrotoxic mycotoxin produced by several fungal strains belonging to the genera Penicillium, Aspergillus, and Monascus. It contaminates various commodities of plant origin, cereals in particular, and is usually found together with another nephrotoxic mycotoxin, ochratoxin A (OTA). These two mycotoxins are believed to be involved in the aetiology of endemic nephropathy. In addition to nephrotoxicity, CTN is also embryocidal and fetotoxic. The genotoxic properties of CTN have been demonstrated with the micronuleus test (MN), but not with single-cell gel electrophoresis. The mechanism of CTN toxicity is not fully understood, especially not whether CTN toxicity and genotoxicity are the consequence of oxidative stress or of increased permeability of mitochondrial membranes. CTN requires complex cellular biotransformation to exert mutagenicity.

Compared with other mycotoxins, CTN contamination of food and feed is rather scarce. However, it is reasonable to believe that humans are much more frequently exposed to CTN than generally accepted, because it is produced by the same moulds as OTA, which is a common contaminant of human food all over the world.

At present, there are no specific regulations either in Croatia or in the European Union concerning CTN in any kind of commodity.
\end{abstract}

KEY WORDS: mycotoxin, nephrotoxicity, organic anion, oxidative stress

Citrinin (CTN, Figure 1) is a secondary product of fungal metabolism, first isolated by Hetherington and Raistrick from a culture of Penicillium citrinum Thom (1). Meanwhile, several other fungal species within the three genera, Penicillium (P. expansum, $P$. verrucosum), Aspergillus (A. terreus), and Monascus (M. ruber) were also found to produce this mycotoxin $(2,3)$. CTN contaminates maize (4), wheat, rye, barley, oats (5), and rice (6). Strains of Monascus are traditionally used in China to produce red and yellow pigments for food (7). Western countries limit the use of synthetic food colorants due to their toxicity and mutagenicity. Natural food pigments obtained from Monascus were good candidates for their substitution because reports on their toxic effects had been scarce for more than 1000 years. However, in 1981 Wong and Koehler (8) isolated from Monascus purpureus a pale yellow pigment monascidin A, which was later determined to be CTN (9). An analysis of traditional Chinese commercial Monascus products obtained by culturing the fungus on steamed rice determined CTN in all samples in the mass fraction range of $0.2 \mu \mathrm{g} \mathrm{g}^{-1}$ to $17.1 \mu \mathrm{g} \mathrm{g}^{-1}(10)$.

$\mathrm{CTN}$ is decomposed at $175^{\circ} \mathrm{C}$ by dry heating, but decomposition temperature decreases to $140{ }^{\circ} \mathrm{C}$ in the presence of a small amount of water $(11,12)$. Decomposition products obtained by heating CTN with water at $140{ }^{\circ} \mathrm{C}$ to $150^{\circ} \mathrm{C}$ were as toxic as or more toxic than CNT. These new toxins are CTN $\mathrm{H}_{1}$ and $\mathrm{CTN} \mathrm{H}_{2}$ (12). The concentration of CTN in the extract of Monascus decreases by $50 \%$ after boiling in water for 20 minutes, which proves that CTN is thermally unstable in aqueous solution (13).

As there are no legal requirements to measure $\mathrm{CTN}$ in food and feed and as probably citrinin $\mathrm{H}_{1}$ is not detectable by usual methods due to its dimeric 
structure, data on food contamination with CTN are scarce. Table 1 shows data for $\mathrm{CTN}$ contamination of some common foodstuffs.

CTN has antibiotic properties against grampositive bacteria, but it has never been used as a drug due to its high nephrotoxicity. The kidney is the major target organ of CTN toxicity, but other target organs such as liver and bone marrow have also been reported (21). Historically, CTN is one of the first isolated mycotoxins; however, the data on the mechanism of its toxicity are still controversial and most have been obtained in vitro. Like other mycotoxins, CTN could be implicated in porcine nephropathy (14). It is frequently found in food and feed in combination with ochratoxin A (OTA), and these two nephrotoxic mycotoxins are suspected to be involved in the aetiology of a human kidney disease called Balkan endemic nephropathy. In the endemic area in Bulgaria, CTN was more common and had higher concentrations in maize and beans intended for human consumption than in the non-endemic area (22). CTN was also found to increase the toxicity of OTA either additively or synergistically (23).

The International Agency for Cancer Research (IARC) classified CTN in Group 3 of carcinogens because of the limited evidence of its carcinogenicity to experimental animals and no evidence for humans (24).

Analytical methods for CTN determination were recently reviewed (12). Common methods for CTN analysis are thin-layer chromatography (TLC), highperformance liquid chromatography (HPLC) with UV or fluorescence detection, and enzyme immunoassays. For qualitative and quantitative determination of CTN LC-MS and GC-MS techniques are used.

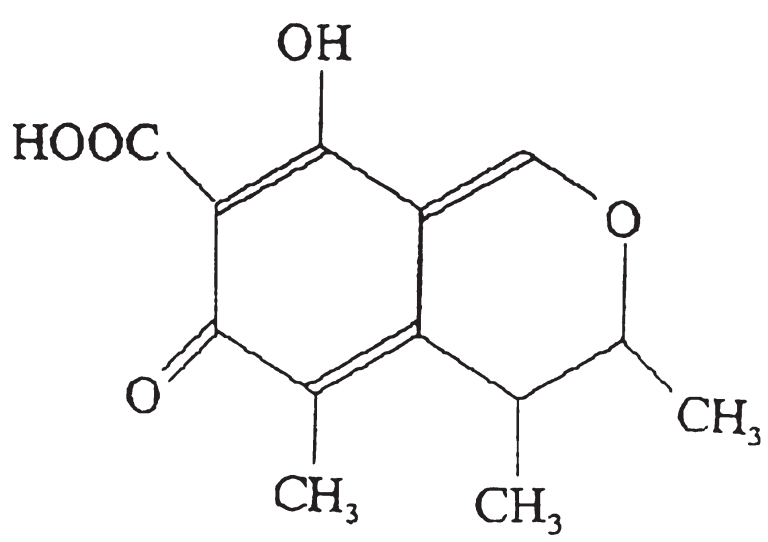

Figure 1 Structural formula of citrinin

\section{TOXICITY, CARCINOGENICITY, AND TERATOGENICITY}

The cytotoxicity of CTN varies remarkably from one cell culture to another (Table 2). CTN applied on cultured hepatoma cells at doses up to $25 \mu \mathrm{mol} \mathrm{L}^{-1}$ was cytostatic, while at concentrations from $50 \mu \mathrm{mol} \mathrm{L}^{-1}$ to $200 \mu \mathrm{mol} \mathrm{L}^{-1}$ it was cytotoxic (29). The effect of CTN on cell viability was tested with the MTT assay on Vero cells from the green monkey kidney treated with increasing CTN concentrations from $0 \mu \mathrm{mol} \mathrm{L}-$ ${ }^{1}$ to $250 \mu \mathrm{mol} \mathrm{L}^{-1}$ (28). Up to the concentration of $60 \mu \mathrm{mol} \mathrm{L}^{-1}$ no significant change in cell viability was observed, and the estimated $\mathrm{IC}_{50}$ of citrinin was about $220 \mu \mathrm{mol} \mathrm{L}^{-1}$ after 48 hours of exposure. With the same exposure time, the $\mathrm{IC}_{50}$ of $\mathrm{CTN}$ for human embryonic cell line was $120 \mu \mathrm{mol} \mathrm{L}^{-1}$. At 24 hours of exposure, the $\mathrm{IC}_{50}$ of $\mathrm{CTN}$ for human promyelocytic leukaemia (HL-60) cells and porcine kidney PK15 cells was $50 \mu \mathrm{mol} \mathrm{L} \mathrm{L}^{-1}$ and $68 \mu \mathrm{mol} \mathrm{L}^{-1}$, respectively $(26,27)$.

Acute $\mathrm{LD}_{50}$ of CTN varies with the route of administration, physiological conditions, and animal species (Table 3). Oral $\mathrm{LD}_{50}$ for rats is $50 \mathrm{mg} \mathrm{kg}^{-1}$ b.w. (30), while subcutaneous $\mathrm{LD}_{50}$ is $67 \mathrm{mg} \mathrm{kg}^{-1}$ b.w. (31). The subcutaneous treatment of pregnant rats with $35 \mathrm{mg} \mathrm{kg}^{-1}$ on days 6,9 , and 10 of pregnancy resulted in $50 \%$ or higher maternal mortality (32). In the Dutch Belted rabbit, oral $\mathrm{LD}_{50}$ is $134 \mathrm{mg} \mathrm{kg}^{-1}$, and in the New Zealand White rabbit it is about $120 \mathrm{mg} \mathrm{kg}^{-1}(33,34)$. Acute lethal doses administered to rabbits, guinea pigs, rats, and swine caused swelling of the kidneys and acute tubular necrosis (36-38).

Subchronical oral treatment of rats with water suspension isolated from a strain of Penicillium viridicatum Westling caused CTN-induced kidney damage characterised by enlarged kidney, hydropic degeneration, loss of brush border, and pyknotic nuclei in the proximal tubules (36). Treatment of mice with weekly injections of CTN $\left(20 \mathrm{mg} \mathrm{kg}^{-1}\right)$ for six weeks resulted in a significant decrease in total bone marrow cells, red blood cell precursors, white blood cell precursors, megakaryocytes, decrease in spleen weight, and decrease in the total spleen cell count (39).

Data on CTN carcinogenicity in the available literature are rather scarce. Kanisawa (40) did not find that CTN caused tumours in mice exposed for to CTN $\left(0 \mathrm{mg} \mathrm{kg}^{-1}, 100 \mathrm{mg} \mathrm{kg}^{-1}\right.$, and $\left.200 \mathrm{mg} \mathrm{kg}^{-1}\right)$ through diet for 70 weeks, while Arai and Hibino (41) reported benign tumours in the kidney of male Fisher 344 rats after CTN treatment for 60 and 80 weeks. 
Table 1 Natural occurrence of citrinin in commodities intended for human consumption

\begin{tabular}{|c|c|c|c|}
\hline $\begin{array}{l}\text { Commodity } \\
\text { contaminated }\end{array}$ & $\frac{\text { Mass fraction of citrinin }}{\mu \mathrm{g} \mathrm{kg}^{-1}}$ & Country & References \\
\hline \multirow{2}{*}{ Barley } & 160 to 2000 & Denmark & 14 \\
\hline & 30 to 480 & Sweden & 15 \\
\hline Apples & 320 to 920 & Portugal & 16 \\
\hline \multirow{2}{*}{ Rice } & 49 to 92 & India & 6 \\
\hline & 700 to 1130 & Japan & \\
\hline \multirow{3}{*}{ Corn flour } & 27 to 73 & Japan & \\
\hline & 10 to 98 & Thailand & 17 \\
\hline & 212 & Burma & \\
\hline Tomatoes & 70 to 760 & Canada & 18 \\
\hline Maize & 12 & India & 19 \\
\hline Fermented maize & 580 & Ghana & 20 \\
\hline
\end{tabular}

CTN is embryocidal and foetotoxic in mice (42). In pregnant Sprague-Dawley rats, CTN given subcutaneously ( $35 \mathrm{mg} \mathrm{kg}^{-1}$ b.w.) on gestation day 3 to 15 did not decrease the number of implants and no gross or skeletal malformations were found, but the foetuses were about $22 \%$ smaller than control (32). CTN injected to pregnant rats of the same strain at a dose of $30 \mathrm{mg} \mathrm{kg}^{-1}$ on gestation days 5 to 14 resulted in a few foetal resorptions and minimal malformations (43). The $\mathrm{LD}_{50}$ of CTN in a 4-day old chicken embryo is $80.5 \mu \mathrm{g}$ per egg (upper limit of $131 \mu \mathrm{g}$, lower limit of $54.3 \mu \mathrm{g})(2)$. CTN doses of $50 \mu \mathrm{g}, 100 \mu \mathrm{g}$, and $150 \mu \mathrm{g}$ per egg, were teratogenic in $46 \%, 48 \%$, and $73 \%$ of surviving chicken embryos, respectively.

\section{EFFECTS ON RENAL FUNCTION AND STRUCTURE}

In a study by Jordan et al., a single intraperitoneal (i.p.) dose of $50 \mathrm{mg} \mathrm{kg}^{-1} \mathrm{CTN}$ caused nephrosis in Sprague-Dawley rats (44). Over the first 48 hours, urine glucose and blood concentrations increased, reaching peak three hours after treatment. Kanisawa found that exposure of male mice to $200 \mathrm{mg} \mathrm{kg}^{-1} \mathrm{CTN}$ through feed for 70 weeks caused very mild renal lesions, but not renal tumours (40).

Citrinin given for six weeks in a daily dose of $2.5 \mathrm{mg} \mathrm{kg}^{-1}$ and $5.0 \mathrm{mg} \mathrm{kg}^{-1}$ in gelatine capsules did not cause clinical or pathological changes in the kidney of young beagle dogs (45). Slow intravenous injection of

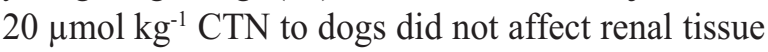
ultrastructure or any of 23 whole blood, plasma, or renal function parameters that were monitored for six hours after treatment (46). On the other hand, $80 \mu \mathrm{mol} \mathrm{kg}{ }^{-1}$ of CTN significantly increased hematocrit and renal excretion rates of proteins and glucose while modest reductions were noted in $\mathrm{C}_{\text {in }}$ (clearance of inulin), renal blood flow, and elimination of inorganic phosphorus. This dose induced ultrastructural lesions in the cells of the S2 proximal tubular segment, the thick ascending limb, the distal convoluted tubule, and the collecting ducts. The glomeruli, S1 and S3 cells of the proximal tubule, and the thin descending and ascending limbs of Henle's loop remained unaffected.

In male New Zealand white rabbits, oral CTN dose of $120 \mathrm{mg} \mathrm{kg}^{-1}$ b.w. produced azotaemia and metabolic acidosis with haemoconcentration and hypokalaemia within 4 to $12 \mathrm{~h}$ (34). In surviving rabbits, oral doses of $80 \mathrm{mg} \mathrm{kg}^{-1}$ and $100 \mathrm{mg} \mathrm{kg}^{-1}$ decreased creatinin clearance which reached the peak on days 2 to 4 , and returned to normal or near normal by day 7 . In a more recent ultrastructural assessment of young growing New Zealand white rabbits exposed to $15 \mathrm{mg} \mathrm{kg}^{-1}$ of CTN through feed, most lesions were observed in the proximal convoluted tubule lining cells, but distal convoluted tubules were unaffected (47). CTN treatment induced nucleus crenation, loss of nucleolus, depletion of cytoplasmic organelles, mitochondrial pleomorphism, nuclear fragmentation, uniform folding of cell membrane, and cytoplasmic vacuolation in proximal convoluted tubules.

In rat liver catalase, butylhydroxitoluene, and dithiothreitol did not protect against swelling and against increased mitochondrial permeability caused by $\mathrm{Ca}^{2+}$ plus citrinin (48). Protection conferred by ATP- $\mathrm{Mg}^{2+}$ and cyclosporine A indicates pore formation. 


\section{DISTRIBUTION, METABOLISM, AND MECHANISMS OF TOXICITY}

The target organ of CTN toxicity is the kidney, but hepatotoxicity has also been reported $(37,49)$. The distribution of ${ }^{14} \mathrm{C}-\mathrm{CTN}\left(3 \mathrm{mg} \mathrm{kg}^{-1}\right)$ was studied in the liver, kidney, and plasma of rats sacrificed at 10 time points after treatment (50). At $0.5 \mathrm{~h}$ after treatment, $14.7 \%$ and $5.6 \%$ of total radioactivity was found in the liver and kidney, respectively. At $6 \mathrm{~h}$, these values decreased to $7.5 \%$ in the liver and $4.7 \%$ in the kidney. Plasma half-lives were $2.6 \mathrm{~h}$ and $14.9 \mathrm{~h}$, respectively. Most of the radioactivity (approx. $80 \%$ ) was found in the urine $(74 \%)$ and faeces $(4 \%)$ in the first 24 $\mathrm{h}$ after treatment. At $72 \mathrm{~h}$ after treatment, $95 \%$ of radioactivity was excreted via urine and faeces.

The major urinary metabolite of CTN is dihydrocitrinone (51). However, CTN as parent compound and not its metabolite was responsible for nephrotoxicity (52). CTN is an organic anion and its effect on renal transport was studied on renal cortical slices of animals treated with a single i.p. injection of $55 \mathrm{mg} \mathrm{kg}^{-14} \mathrm{C}-\mathrm{CTN}$. Animals were killed $72 \mathrm{~h}$ after dosing, when the effect on renal tubular transport was expected to be the highest. The importance of anion transport system was demonstrated by the reduced uptake of ${ }^{14} \mathrm{C}$-CTN in the presence of probenecid, a specific inhibitor of anion transport (53).

In vitro studies on various cultured cells gave contradictory results about the involvement of oxidative stress in CTN toxicity. Ribeiro et al. reported that CTN modified antioxidative enzymatic defences of rat liver cells by inhibiting GSSG-reductase and transhydrogenase (54). However, no effect was observed on GSH-peroxidase, catalase, glucose 6phosphate, 6-phosphoguconate dehydrogenase, and superoxide dismutase. CTN increased formation of reactive oxygen species, stimulating the production of superoxide anion in the respiratory chain. The authors concluded that oxidative stress was an important mechanism in CTN-induced citotoxicty and cellular death in several tissues.
The importance of oxidative stress in CTN toxicity was confirmed by microarray studies of CTN effects of citrinin in yeast cells (55) and of the viability of Vero cells exposed to CTN and antioxidant vitamin E (56). Aleo et al. (57) used suspensions of renal proximal tubules (RPT) and found that CTN increased lipid peroxidation and that deferoxamine (which prevents iron-mediated lipid peroxidation) did not protect RPT from CTN-induced cell death. The possibility that CTN may alter mitochondrial function, put forward by this group of authors, was corroborated by studies with baby hamster kidney cells (58). Electron microscopy showed that CTN significantly affected normal mitochondria with swelling and cell death. Chagas et al. have suggested that CTN decreases $\mathrm{Ca}^{2+}$ accumulation in the matrix by inhibiting its influx and increasing its efflux (59).

CTN was found to cause apoptosis in human promyelocytic leukemia (HL-60) cells and porcine kidney PK15 cells $(26,27)$. The number of apoptotic cells increased dramatically at doses higher than $\mathrm{LC}_{50}$ $(50 \mu \mathrm{g})$. CTN induced dose-dependent formation of caspases 3,6,7, and 9, but not caspase 8. Furthermore, the authors noted increased cytochrome $\mathrm{c}$ release from mitochondria into the cytoplasm, and cytochrome $\mathrm{c}$ is known to activate apoptosis-regulating caspases 3 , 6,7 , and 9. This suggests that CTN induces apoptosis through cytochrome $\mathrm{c}$ and not through oxidative stress. This has been corroborated by the finding that CTNinduced increase in caspase 3 catalytic activity could not be suppressed by antioxidants.

CTN reduces GSH levels in a dose- and timedependent manner in human alveolar epithelial cells A549 at non-toxic concentrations (60). This effect is the sign of oxidative stress and may contribute to inflammation in people exposed to moulds.

\section{GENOTOXICITY}

Genotoxicity of CTN has not been unequivocally established because various test systems gave

Table 2 Citrinin $I C_{50}$ values in different cell cultures

\begin{tabular}{lcccc}
\hline \multirow{2}{*}{ Cell culture } & \multicolumn{3}{c}{$\mathbf{L C}_{\mathbf{5 0}} / \boldsymbol{\mu} \mathbf{m o l ~ \mathbf { ~ L } ^ { - 1 }}$} & \multirow{2}{*}{ Reference } \\
\cline { 2 - 3 } & $\mathbf{2 4 \mathbf { h }}$ & $\mathbf{4 8} \mathbf{~ h}$ & $\mathbf{7 2} \mathbf{~ h}$ & \\
\hline Human embryonic cell line (HEK293) & - & 120 & 80 & 25 \\
\hline Human promyelocytic leukemia (HL-60) cells & 50 & & & 26 \\
\hline Porcine kidney PK15 & 68 & & 27 \\
\hline Vero cells & & 220 & 28 \\
\hline
\end{tabular}


Table 3 Citrinin $L D_{50}$ values by way of administration and by experimental animal

\begin{tabular}{lcccc}
\hline Species & Sex and age & $\begin{array}{c}\text { Route of } \\
\text { administration }\end{array}$ & $\mathbf{L D}_{\mathbf{5 0}} / \mathbf{m g ~ k}^{\mathbf{1}} \mathbf{b . w .}$ & Reference \\
\hline Rat & $\mathrm{M}$ & oral & 50 & 30 \\
\hline Rat & - & s.c. & 67 & 31 \\
\hline Rat & - & i.p. & 67 & 31 \\
\hline Rat & F, pregnant & s.c. & $<35$ & 32 \\
\hline Mouse & M, BALB/C & i.p. & 45 & 28 \\
\hline Guinea-pig & - & i.p. & 37 & 31 \\
\hline Rabbit & Dutch Belted rabbit & oral & 134 & 33 \\
\hline Rabbit & New Zealand White rabbit & oral & 1120 & 34 \\
\hline Rabbit & - & i.v. & 19 & 31 \\
\hline Turkey & M, 7 day-old & oral & 56 & 35 \\
\hline Pekin duck & M, 7 day-old & oral & 57 & 35 \\
\hline
\end{tabular}

both positive and negative results. An increase in DNA damage was detected using single cell gel electrophoresis (comet test) in Vero cells exposed $24 \mathrm{~h}$ to CTN (28). However, the same method gave negative results in human-derived liver cells (HepG2) (61) and human embryonic kidney cells (HEK293) (25) no matter if Fpg was present or not. This suggests that CTN-induced oxidative stress did not affect DNA.

In contrast to negative results, various cell cultures exposed to CTN showed a significant increase in micronucleus $(\mathrm{MN})$ frequency. Twenty-four-hour exposure of PK 15 cells to $30 \mu \mathrm{mol} \mathrm{L}-1$ of CTN resulted in a significant increase in $\mathrm{MN}$ frequency $(9.5 \%$ ) over control $(2.75 \%)(27)$. This increase was also noticed in HEPG2 cells, human lymphocytes, and Chinese hamster V79 cells, but CTN concentrations showing genotoxicity differed between cell cultures (61-63).

\section{MUTAGENICITY}

CTN mutagenicity testing is also inconclusive. CTN was not mutagenic when tested with or without S9-mix (HepG2-derived enzyme homogenate) activation in TA-98 and TA-100 strains of Salmonella typhymurium (61). In another study, three additional strains (TA-1535, TA-1538 and TA-97) of $S$. typhymurium were used to test CTN mutagenicity (10), but no mutagenic effect was observed. However, when a primary hepatocyte culture was added, strain TA98 showed a significant dose-dependent mutagenic response, and strain TA-100 a slight positive response. These results indicate that $\mathrm{CTN}$ requires a complex cellular biotransformation to become mutagenic.
Several studies have shown clastogenic CTN activity in vitro and in vivo, including a variety of chromosomal aberrations, save for sister chromatid exchange (SCE). In a study of Chinese hamster ovary cells and HEK293, CTN did not produce any significant difference in either SCE frequency or DNA gaps and breaks (25).

Thust and Kneist established CTN-induced SCEs in Chinese hamster V79-E cells in the presence of S9-mix (64). They also observed the aneuploidic potential of CTN. CTN was found to be aneugenic because it caused concentration-dependent mitotic arrest, regardless of incubation time. This effect was reversible after the removal of CTN (64).

Jeswal (65) has found that CTN induces chromosome abnormalities and breaks in bone marrow cells in young weanling mice. The most frequent $\mathrm{CTN}$-induced chromosome aberrations found in another study by Bouslimi et al. in bone marrow cells of adult mice included breaks, centric fusions, rings, and gaps (28).

\section{CONCLUSIONS}

Although CTN is a nephrotoxic compound in experimental animals, the mechanism of its toxicity is not fully understood. Combined with OTA, it may be involved in the aetiology of endemic nephropathy. However, little is known about human exposure to this mycotoxin through food because there is no legal obligation to measure it in Croatia or in the European Union. 


\section{REFERENCES}

1. Hetherington AC, Raistrick H. Studies on biochemistry of microorganisms. Part XIV. On the production and chemical constitution of a new yellow coloring matter, citrinin produced from glucose by Penicillium citrinum Thom. Phil Trans Roy Soc London, Ser B 1931;220:269-96.

2. Ciegler A, Vesonder RF, Jackson LK. Production and biological activity of patulin and citrinin from Penicillium expansum. Appl Environ Microbiol 1977;33:1004-6.

3. Bragulat MR, Martínez E, Castellá G, Cabañes FJ. Ochratoxin A and citrinin producing species of the genus Penicillium from feedstuffs. Int J Food Microbiol 2008;126:43-8.

4. Nelson TS, Kirby LK, Beasley JN, Johnson ZB, Ciegler A The effect of drying method and storage time on citrinin activity in corn. Poult Sci 1985;64:464-8.

5. Scott PM, van Walbeek W, Kennedy B, Anyeti B. Mycotoxins (ochratoxin A, citrinin and sterigmatocystin) and toxigenic fungi in grains and other agricultural products. J Agric Food Chem 1972;20:1103-9.

6. Tanaka K, Sago Y, Zheng Y, Nakagawa H, Kushiro M. Mycotoxins in rice. Int J Food Microbiol 2007;119:59-66.

7. Xu G, Lu C, Mu X, Chen J, Chen Y, Gu Y, Wu Y, Sheng F, $\mathrm{Wu} \mathrm{M}$. A study on the production of citrinin by Monascus spp. Arch Lebensmittelhyg 1999;50:88-91.

8. Wong HC, Koehler PE. Production and isolation of an antibiotic from Monascus purpureus and its relationship to pigment production. J Food Sci 1981;46:589-92.

9. Blanc PJ, Laussac JP, Le Bars J, Le Bars P, Loret MO, Pareilleux A, Prome D, Prome JC, Santerre AL, Goma G. Characterization of monascidin A from Monascus as a citrinin. Int J Food Microbiol 1995;27:201-13.

10. Sabater-Vilar M, Maas RFM, Fink-Gremmels J. Mutagenicity of commercial Monascus fermentation products and the role of citrinin contamination. Mutat Res 1999;444:7-16.

11. Kitabatake N, Ben Trivedi A, Doi E. Thermal decomposition and detoxification of citrinin under various moisture conditions. J Agric Food Chem 1991;39:2240-4.

12. Xu B-J, Jia X-Q, Gu L-J, Sung C-K. Review on the qualitative and quantitative analysis of the mycotoxin citrinin. Food Control 2006; 17:271-85.

13. Shu PY, Lin CH. Simple and sensitive determination of citrinin in Monascus by GC-selected ion monitoring mass spectrometry. Anal Sci 2002;18:283-7.

14. Krogh P, Hald B, Pedersen EJ. Occurrence of ochratoxin $\mathrm{A}$ and citrinin in cereals associated with mycotoxic porcine nephropathy. Acta Pathol Microbiol Scand B 1973;81:68995.

15. Hökby F, Hult K, Gatenbeck S, Rutqvist H. Ochratoxin A and citrinin in 1976 crop of barley stored on farms in Sweden. Acta Agric Scand 1979;29:174-8.

16. Martinis ML, Gimeno A, Martinis HM, Bernardo F. Cooccurrence of patulin and citrinin in Portuguese apples with rotten spots. Food Addit Contam 2002;19:568-74.

17. Nishijima M. Survey for mycotoxins in commercial foods. Dev Food Sci1984;7:172-81.

18. Harwig J, Scott P, Stoltz DR, Blanchfield BJ. Toxins of molds from decaying tomato fruit. Appl Environ Microbiol 1979;38:267-74.

19. Janardhana GR, Raveesha KA, Shetty HS. Mycotoxin contamination of maize grains grown in Karnataka (India). Food Chem Toxicol 1999;37:863-8.
20. Vella F, Kpodo K, Sorensen AK, Jakobsen M. The occurrence of mycotoxins in fermented maize products. Food Chem 1995;56:147-53.

21. Gupta M, Sasmal D, Bandyopadhyay S, Bagchi G, Chatterjee $\mathrm{T}$, Dey S. Hematological changes produced in mice by ochratoxin A and citirinin. Toxicology 1983; 26:55-62.

22. Petkova-Bocharova T, Castegnaro M, Michelon J, Maru V. Ochratoxin A and other mycotoxins in cereals from an area of Balkan endemic nephropathy and urinary tract tumours in Bulgaria. In: Castegnaro M, Pleština R, Dirheimer G, Chernozemsky IN, Bartsch H, editors. Mycotoxins, endemic nephropaty and urinary tract tumours. Lyon: IARC; 1991. p. 83-7.

23. Speijers GJA, Speijers MHM. Combined toxic effects of mycotoxins. Toxicol Lett 2004;153:91-8.

24. International Agency for Research of Cancer (IARC). Some naturally occurring and synthetic food components, furocumarins and ultraviolet radiation. IARC monographs on the evaluation of the carcinogenic risk of chemicals to humans. Vol. 40. Lyon: IARC; 1986. p. 67-82.

25. Liu BH, Yu FY, Wu TS, Li SY, Su MC, Wang MC, Shih SM. Evaluation of genotoxic risk on oxidative DNA damage in mammalian cells exposed to mycotoxins, patulin and citrinin. Toxicol Appl Pharmacol 2003;191:255-63.

26. Yu FY, Liao YC, Chang $\mathrm{CH}$, Liu BH. Citrinin induces apoptosis in HL-60 cells via activation of the mitochondrial pathway. Toxicol Lett 2006;161:143-51.

27. Šegvić Klarić M, Želježić D, Domijan A-M, Peraica M, Pepeljnjak S. Citotoxicity, genotoxicity and apoptosis induced by ochratoxin A and citrinin in porcine kidney PK15 cells: Effects of single and combined mycotoxins. Toxicol Lett 2007;172(Suppl. 1):S56.

28. Bouslimi A, Bouaziz C, Ayed-Boussema I, Hassen W, Bacha $\mathrm{H}$. Individual and combined effects of ochratoxin $\mathrm{A}$ and citrinin on viability and DNA fragmentation in cultured Vero cells and on chromosome aberrations in mice bone marrow cells. Toxicology 2008;251:1-7.

29. Lorkowski G, Creppy EE, Beck G, Dirheimer G, Röschenthaler R. Inhibitory action of citrinin on cultured hepatoma cells. Food Cosmet Toxicol 1980;18:489-91.

30. Sakai F. An experimental study on the toxic effect, especially on the kidney of "yellowed rice" polluted by Penicillium citrinum Thom, as well as of citrinin, a pigment isolated from the mould. Folia Pharmacol Jpn 1955;51:431-42.

31. Ambrose AM, DeEds F. Acute and subacute toxicity of pure citrinin. Proc Soc Exp Biol Med 1945;59:289-91.

32. Reddy RV, Mayura K, Hayes AW, Berndt W. Embryocidal teratogenic and fetotoxic effects of citrinin in rats. Toxicology 1982;25:150-60.

33. Hanika C, Carltno WW, Tuite J. Citrinin mycotoxicosis in the rabbit. Food Chem Toxicol 1983;21:487-93.

34. Hanika C, Carlton WW, Boon GD, Tuite J. Citrinin mycotoxicosis in the rabbit: clinicopathological alterations. Food Chem Toxicol 1984;22:999-1008.

35. Mehdi NAQ, Carlton WW, Tuite J. Acute toxicity of citrinin in turkeys and ducklings. Avian Pathol 1983;12:221-33.

36. Friis P, Hasselager E, Krogh P. Isolation of citrinin and oxalic acid from Penicillium viridicatum Westling and their nephrotoxicity in rats and pigs. Acta Path Microbiol Scand 1969:77:559-60.

37. Ambrose AM, DeEds F. Some toxicological and pharmacological properties of citrinin. J Pharmacol Exp Ther 1946;88:173-86. 
38. Krogh P, Hasselager E, Friis P. Studies on fungal nephrotoxicity. II Isolation of 2 nephrotoxic compounds from Penicillium viridicatum West: Citrinin and oxalic acid. Acta Pathol Microbiol Scand 1970;B78:401-13.

39. Gupta M, Sasmal D, Bandyopadhyay S, Bagchi G, Chatterjee T, Dey S. Hematological changes produced in mice by ochratoxin A and citrinin. Toxicology 1983;26:55-62.

40. Kanisawa M. Synergistic effect of citrinin on hepatorenal carcinogenesis of ochratoxin A in mice. Dev Food Sci 1984;7:245-54

41. Arai M, Hibino T. Tumorigenicity of citrinin in male F344 rats. Cancer Lett 1983;17:281-7.

42. Hood RD, Hayes AW, Scammell JG. Effects of prenatal administration of citrinin and viriditoxin to mice. Food Cosmet Toxicol 1976;14:175-8.

43. Mayura K, Parker R, Berndt WO, Phillips TD. Effect of simultaneous prenatal exposure to ochratoxin A and citrinin in the rat. J Toxicol Environ Health 1984;13:553-61.

44. Jordan WH, Carlton WW, Sansing GA. Citrinin mycotoxicosis in the rat. II. Clinicopathological observations. Food Cosmet Toxicol 1978;16:441-7.

45. Carlton WW, Sansing G, Szczech GM, Tuite J. Citrinin mycotoxicosis in beagle dogs. Food Cosmet Toxicol 1974;12:479-90.

46. Krejci ME, Bretz NS, Koechel DA. Citrinin produces acute adverse changes in renal function and ultrastructure in pentobarbital-anesthetized dogs without concomitant reductions in [potassium] plasma. Toxicology 1996;106:16777.

47. Kumar M, Dwivedi P, Sharma AK, Singh ND, Patil RD. Ochratoxin A and citrinin nephrotoxicity in New Zealand White rabbits: and ultrastructural assessment. Mycopathologia 2007;163:21-30.

48. Da Lozzo EJ, Oliveira MB, Carnieri EG. Citrinin-induced mitochondrial permeability transition. J Biochem Mol Toxicol 1998;12:291-7.

49. Carlton WW, Tuite J. Metabolites of P. virdicatum toxicology. In: Rodricks J, Hesseltine V, Mehlman M, editors. Mycotoxins in human and animal health. Park Forest South (IL): Pathotox Publishers Inc.; 1977. p. 525-41.

50. Phillips RD, Berndt WO, Hayes AW. Distribution and excretion of $\left[{ }^{14} \mathrm{C}\right]$ citrinin in rats. Toxicology 1979;12:28598.

51. Dunn BB, Stack ME, Park DL, Joshi A, Friedman L, King $R L$. Isolation and identification of dihydrocitrinone, a urinary metabolite of citrinin in rats. J Toxicol Environ Health 1983;12:283-9

52. Berndt WO, Hayes AW. The effect of probenecid on citrinin-induced nephrotoxicity. Toxicol Appl Pharmacol 1982;64:118-24.
53. Berndt WO. Transport of citrinin by rat renal cortex. Arch Toxicol 1983:54:35-40.

54. Ribeiro SMR, Chagas GM, Campello AP, Klüppel LW. Mechanism of citrinin-induced dysfunction of mitochondria. V. Effect on the homeostasis of the reactive oxygen species. Cell Biochem Funct 1997;15:203-9.

55. Iwahashi H, Kitagawa E, Suzuki Y, Ueda Y, Ishizawa Y, Nobumasa H, Kuboki Y, Hosoda H, Iwahashi Y. Evaluation of toxicity of the mycotoxin citrinin using yeast ORF DNA microarray and Oligo DNA microarray. BMC Genomics 2007;8:95.

56. El Golli E, Hassen W, Bouslimi A, Bouaziz C, Ladjimi MM, Bacha H. Induction of Hsp 70 in Vero cells in response to mycotoxins. Cytoprotection by sub-lethal heat shock and by vitamin E. Toxicol Lett 2006;166:122-30.

57. Aleo MD, Wyatt RD, Schnellmann RG. The role of altered mitochondrial function in citrinin-induced toxicity to rat renal proximal tubule suspensions. Toxicol Appl Pharmacol 1991;109:455-63.

58. Chagas GM, Wambier Klüppel ML, Campello AP, Buchi DF, Oliveira MBM. Alterations induced by citrinin in cultured kidney cells. Cell Struct Funct 1994;19:103-8.

59. Chagas GM, Oliveira MBM, Campello AP, Kluppel MLW. Mechanism of citrinin-induced dysfunction of mitochondria. IV. Effect on $\mathrm{Ca}^{2+}$ transport. Cell Biochem Funct 1995;13:539.

60. Johannessen LN, Nilsen AM, Lovik M. Mycotoxin-induced depletion of intracellular glutathione and altered cytokine production in the human alveolar epithelial cell line A549. Toxicol Lett 2007;168:103-12.

61. Knasmüller S, Cavin C, Chakraborty A, Darroudi F, Majer BJ, Huber WW, Ehrlich VA. Structurally related mycotoxins ochratoxin $\mathrm{A}$, ochratoxin $\mathrm{B}$, and citrinin differ in their genotoxic activities and in their mode of action in humanderived liver (HepG2) cells: implications for risk assessment. Nutr Cancer 2004;50:190-7.

62. Dömnez-Altuntas H, Dumlupinar G, Imamoglu N, Hamurcu Z, Liman BC. Effects of the mycotoxin citrinin on micronucleus formation in a cytokinesis-block genotoxicity assay in cultured human lymphocytes. J Appl Toxicol 2007;27:337-41.

63. Pfeiffer E, Gross K, Metzler M. Aneuploidogenic and clastogenic potential of the mycotoxins citrinin and patulin. Carcinogenesis 1998;19:1313-8.

64. Thust R, Kneist S. Activity of citrinin metabolized by rat and human microsome fractions in clastogenicity and SCE assay on Chinese hamster V79-E cells. Mutat Res 1979;67:321-30.

65. Jeswal P. Citrinin-induced chromosomal abnormalities in the bone marrow cells of Mus musculus. Cytobios 1996;86:2933. 


\section{Sažetak}

\section{TOKSIKOLOŠKA SVOJSTVA CITRININA}

Citrinin (CTN) nefrotoksičan je mikotoksin koji proizvode različiti sojevi plijesni iz rodova Penicillium, Aspergillus i Monascus. CTN se može naći u različitim namirnicama biljnog podrijetla, osobito u žitaricama i obično se nalazi zajedno s drugim nefrotoksičnim mikotoksinom, okratoksinom A (OTA). Pretpostavlja se da je izloženost ovim mikotoksinima povezana s nastankom endemske nefropatije. Osim što je nefrotoksičan, CTN je još i embricidan i fetotoksičan. Na genotoksičnost citrinina upućuje pozitivan mikronukleusni test na različitim vrstama staničnih kultura, iako je kometski test negativan. Mutagenost CTN-a očituje se na različitim vrstama stanica samo ako se pridodaju stanični aktivatori kao npr. S9-mix. Mehanizam toksičnosti CTN-a nije potpuno razjašnjen pa još uvijek traje znanstvena rasprava je li njegova toksičnost i genotoksičnost posljedica oksidacijskog stresa ili povećane permeabilnosti mitohondrijskih membrana. U dostupnoj literaturi podaci o kontaminiranosti hrane i krmiva ovim mikotoksinom mnogo su rjeđi od onih za druge mikotoksine. Može se pretpostaviti da su ljudi često izloženi ovom mikotoksinu zato što ga proizvode iste plijesni koje proizvode i OTA, a one kontaminiraju hranu po cijelom svijetu.

U Hrvatskoj i u zemljama Europske Unije ne postoje zakonske odredbe o dopuštenim granicama CTN-a u bilo kojoj vrsti hrane.

KLJUČNE RIJEČI: mikotoksin, nefrotoksičnost, oksidacijski stres, organski anion

\section{CORRESPONDING AUTHOR:}

Dubravka Flajs, BSc

Institute for Medical Research and Occupational Health

P. O. Box 291, HR-10001 Zagreb, Croatia

E-mail:dflajs@imi.hr 